oriented so far as possible at right angles to the prevailing wind and spaced at intervals through the countryside : their function is to protect agricultural cultivation, especially cocoa ; to assist in maintaining the necessary environment of a closed forest climate, and to afford additional lines of defence against the encroachment of open-forest conditions. How far this aspiration will be possible in view of the considerable area of forest which has already been swept away or reduced to a condition in which it will prove useless for the purpose in view it is impossible as yet to say. But this matter has not been taken up any too soon.

It is apparent from the report that the Conservator has been able to increase considerably his gazetted staff (from 12 in 1934 to 18 in 1936) and is making progress in an even more desirable matter-that is, in "bringing the Forest Department district organization into line with the political district organization which itself follows tribal distribution as far as possible. At present forest districts consist of two to three political districts".

With a strengthened staff, the Conservator rightly decided that the first work to deal with was the selection, demarcation and cultivation of the forest reserves still demanding constitution, and a considerable amount of work in this connexion was undertaken during the year.
With the sub-division of the country into definito forest districts, each to be in charge of an assistant conservator of forests, the management of the forest districts will receive more attention and the advance in the introduction of working plans will prove feasible, when sufficient stock mapping of the growing stock in the forests has been accomplished.

Fuel will be required so far as can be foreseen in increasing amounts in the Colony, both for domestic consumption and for power in connexion with waterwork schemes. The exotics Cassia siamea and the Indian neem are both giving satisfactory results, ss elsewhere in West Africa. Good fuel wood is successfully produced in seven years or less. The total area of fuel plantations amounts to 1,000 acres, the greatest area at Achimota, where the highly successful School is situated, within a short distance of Accra, the capital on the Coast. Other plantations of the same type exist at Cape Coast, Kumasi and other centres. Assistance is also given by the Department in connexion with water-works schemes. The sus. tained supply of fuel to the mines is proving a more difficult matter.

The report has some interesting remarks on the subject of the prevalent practice of firing the socalled open or savannah forest lands and shifting cultivation. It is the most informative forest report on the Colony which has appeared for some time.

\title{
Oak-galls in Theophrastus
}

$\mathrm{P}$ ROF. GUSTAV SENN, of Basle, has published a short but interesting note on this subject (Verh. Schweiz. Naturforschende Gesellschaft, Solothurn, p.372; 1936). Theophrastus mentions, in his "Historia Plantarum", no less than ten species of oak-galls. Some are well known and unmistakable, such as the common Turkey or Aleppo gall; and one, or the insect which produces it, Andricus Theophrasteus, bears the old Greek's name. But no one seems ever to have studied the Theophrastean account as a whole, and even Sir Arthur Hort made no attempt to identify the several species. Prof. Senn finds little difficulty in doing so, and the result is a remarkable testimony to Theophrastus's diagnostic skill.

The 'little gall' with which the account begins (H.P., 3, 7, 4) is the valuable Aleppo gall, or "ink marble', formed by Cynips tinctoria. The common 'black resinous' gall is the Bassorah gall, made by $C$. insana; it is the only one with a coat of resin. A scarce one, very hard in texture, mulberry-like in form, is identified by Prof. Senn as the gall of $C$. culiciformis. Another, phalliform in shape, grow. ing into something like a bull's head at one end and with a hard interior like an olive-stone, is identified as the gall of $C$. Quercus-Tozce. Fluffy balls, serving for lamp-wicks, are the woolly or cotton galls of Andricus Theophrasteus, akin I suppose to $A$. ramuli; and other hairy or bristly galls, covered with sweet honey-drops in spring, but quite useless, are those of $A$. lucidus. Certain stalkless galls, looking like a cluster of leaf-scales and growing in the axil of a leaf or twig, are the hop galls or artichoke galls of $A$. fecundator. The rare, elongated, close-textured foliaceous balls are the galls of A. multiplicatus; and, last of this catalogue, the clear juicy globules, growing on the midrib of a leaf, are the well-known currant galls of Neuroterus baccarum.

In another passage (H.P., 3, 3, 8), Theophrastus mentions, with the same brief accuracy, the galls which the tanner uses and the black ones which serve for the dyeing of wool; these being, once again, the Aleppo galls of $C$. tinctoria and the Bassorah galls of $C$. insana. A little gall, something like the Aleppo gall but smoother, and of no commercial value, is in all probability the oak-marble, or oakapple, of $C$. Kollari. Connold, in his "British Oak. galls" says of it: " $C$. tinctoria bears a very close resemblance to $C$. Kollari, and many specimens of the latter might easily be mistaken for the Aleppo gall" ; but the latter, he adds, yields 40 per cent of tannin, while $C$. Kollari gives only 17 per cent. This last identification may be a little doubtful, but the other nine oak-galls mentioned and characterized in a word or two by Theophrastus are easily and safely identified. The fact is that, great philosophic biologist as Aristotle was, Theophrastus was far ahead of him as an observer and recorder of species from a modern botanist's point of view.

Sir Thomas Browne, in his notes on the "Natural History of Norfolk" (ed. T. Southwell, 1902), found on the oak just about as many galls as Theophrastus know, and characterized them with equal skill. His "Juli pilulce, little balls on the flower catkins", are a form of the currant gall; his excrementum lanatum is a woolly gall; and his capitula squamea jacece amula, "little scaly heads like the heads of knapweed", are without doubt our hop or artichoke galls.
D. W. T. 